\title{
Att administrera övergångar: En analys av Skolverkets stödmaterial om övergångar i skolan
}

\section{Lina Lago och Maria Simonsson, Linköpings universitet}

Vilken kunskap finns tillgänglig för att underlätta skolans arbete med barns övergångar och vilket fokus har denna information? Vi har analyserat Skolverkets stödmaterial om övergångar för att se vilka riktlinjer som verksamheterna har att förhålla sig till. Kontinuitet framstår som önskvärt och råden handlar i hög utsträckning om hur skolan och förskolan ska arbeta med att skapa rutiner för detta, men också om vad det är för typ av information som ska överlämnas.

\section{Introduktion}

Syftet med denna artikel är att synliggöra vad det är för kunskap som framförs i

Skolverkets (2014a) stödmaterial "Övergångar inom och mellan skolor och skolformer". Vi är intresserade av hur överlämnande av information beskrivs och vem som görs aktiv i denna konstruktion, för att på så sätt visa på hur övergångar är föremål för styrning (Davies \& Harré, 1990; Foucault, 1991, 2003; Rose, 1999). I denna artikel fokuserar vi på de yngre barnens övergångar, det vill säga övergångar inom och mellan förskola, förskoleklass och grundskolans tidigare år.

Skolverkets (2014a) nyligen utgivna stödmaterial om övergångar är tänkt "att ge stöd och idéer om hur förskola och skola kan arbeta för att ge barn och elever en kontinuitet i sin skolgång” (ibid., s. 6). Skolverket pekar på vikten av samverkan mellan olika förskole- och skolenheter vid övergångar och lyfter fram barn och elever i behov av särskilt stöd som extra utsatta vid övergångar. En särskild risk vid övergångar är, enligt Skolverket, att dokumentation och information om barn och elever riskerar att gå förlorad och att de av den anledningen inte får det stöd som de är i behov av. Vi behöver veta mera om vad det är för tankefigurer som tecknas kring övergångar i detta 


\section{VENUE}

stödmaterial, då det utgör en av utgångspunkterna för hur övergångsarbetet kommer att skapas och formas i verksamheterna.

Övergångar kan sägas handla om förändringar i och byte av sammanhang. En övergång kan alltså sägas innebära förändringar i de institutionella villkoren, per definition en diskontinuitet (t.ex. Corsaro \& Molinari, 2005; Ecclestone, Biesta \& Hughes, 2010). I tidigare forskning har kontinuitet beskrivits som något önskvärt. Det som framför allt anses skapa kontinuitet är att övergången upplevs som tydlig och trygg (t.ex. Margetts, 2002; Sutton, Muller \& Langenkamp, 2013). Samtidigt visar annan forskning på att viss diskontinuitet i samband med övergångar kan ses som positiv då barnen ofta förväntar sig förändring och ser förändring som en del av att bli äldre eller mer kompetent (t.ex. Ackesjö, 2013; Corsaro \& Molinari, 2005; Lago, 2014).

\section{Skapa, producera och konsumera information}

Vår analys av Skolverkets material visar att det främst är information och överlämnande av information som betonas som ett verktyg för att skapa kontinuitet vid övergångar. Råden handlar i hög utsträckning om hur skolan och förskolan ska arbeta med att skapa rutiner för detta men också om vad det är för typ av information som ska överlämnas. Vi ser information som kunskapsproduktion och produktionen av "sanningar" (jmf Foucault, 1991) om barnen och om övergången.

\section{Att skapa information}

Vad är det då för kunskap som produceras i stödmaterialet från Skolverket? Barn och elever är synliga i materialet, men de beskrivs ganska genomgående som föremål för institutionernas omsorg. Det är information om barnen/eleverna som ska lämnas över från skolenhet till skolenhet, från skolform till skolform. Det är också information om enskilda barn som skrivs fram i Skolverkets material. Informationen som ska överlämnas ska ha "fokus på barnets eller elevens förutsättningar" (Skolverket, 2014a, s. 28). Skolverket lyfter här fram vikten av att informationen ska präglas av ett professionellt förhållningssätt och tydlighet och att dokumentationen "inte innehåller värdeladdade ord eller personliga egenskaper" (ibid., s. 32). Det handlar alltså om hur enskilda barn/elever är (om än inte i värderande ordalag), vad den enskilde har för behov, den individuella prestationen och så vidare. Detta kan vi relatera till att dessa kunskaper (information) är nödvändiga i de administrativa och ekonomiska 


\section{VENUE}

strukturerna för att kunna skapa kontinuitet. Ett annat sätt på vilket barn/elever syns i materialet är genom att Skolverket betonar att barnperspektiv ska genomsyra arbetet med övergångar. Det är dock alltid någon annan, ofta inte specificerat vem, som ska anlägga ett sådant perspektiv. Barnperspektiv blir alltså de vuxnas perspektiv på barnen.

Det vi har uppmärksammat gällande övergången mellan förskola och förskoleklass, är att Skolverket i liten utsträckning skriver om att information som rör verksamhet, grupper, arbetssätt eller innehåll ska lämnas över (Skolverket, 2014a). Fokus i den information som ska lämnas över är alltså vem individen anses vara och inte det som individen har erfarenheter av, det vill säga de sammanhang som barnet/eleven har befunnit sig i innan övergången. Vi kan dra slutsatsen, utifrån våra analyser, att Skolverkets stödmaterial (2014a) förespråkar en homogenisering av den typ av information som ska skapas och överlämnas.

\section{Administrativa rutiner för överblick och kontroll}

Våra analyser av Skolverkets material visar också hur överlämnande av information mellan olika verksamheter är tänkt att gå till. I materialet ligger fokus på skolan/förskolan och dess arbete med övergångar. Samverkan mellan skolformer, årskurser, stadier med mera skrivs fram som viktigt. Det innebär att det är institutionerna som görs aktiva i materialet. Redan i inledningens första mening klargörs att "Förskola och skola har i uppdrag att samarbeta för att stödja barns och elevers allsidiga utveckling och lärande i ett långsiktigt perspektiv" (Skolverket, 2014a, s. 8).

Denna mening ringar ganska väl in hur övergångsarbetet skrivs fram i Skolverkets stödmaterial. Det är institutionerna/verksamheterna som ska producera, överlämna och ta emot information. Information är ett nyckelbegrepp i Skolverkets text och skrivningar om information, överlämnande av information och vikten av att mottagande skolenhet får rätt information återkommer. I detta blir övergångsarbetet något som ska hanteras på institutionsnivå, vilket gör att det handlar mer om administrativa rutiner, program för informationsöverlämnande och rutiner för samverkan mellan institutioner än om vardagsarbete som involverar aktiva lärare ${ }^{i}$, barn/elever och vårdnadshavare. Fokuset på den administrativa nivån förstärks också av att ett särskilt kapitel handlar om "Stöd för övergångsarbetet på central nivå" (Skolverket, 2014a, s. 34). 


\section{VENUE}

Beskrivningarna av övergångsarbetet är i hög utsträckning beskrivningar av institutioner och administrativa rutiner. Målet, det vill säga den kontinuitet som man vill uppnå, handlar om att skapa sådana rutiner som gör att så mycket och så relevant information som möjligt ska överlämnas mellan de institutioner mellan vilka barn gör övergångar. "Övergångar handlar om att den avlämnande verksamheten ger relevant information till den nya mottagande verksamheten" skriver Skolverket (2014a, s. 9). Information och informationsöverlämnande blir ett sätt att skapa en överblick och kontroll över det som sker när barn gör övergångar mellan olika verksamheter. I detta blir det viktigt att skapa tydliga administrativa rutiner som gör att rätt information når fram till rätt verksamhet, allt detta för barnets bästa (Skolverket, 2014a). På det sättet är Skolverkets material ett stöd för den administrativa nivån snarare än lärare och barns/elevers vardagsarbete med att göra övergångar.

\section{Sammanfattning och implikationer}

Övergångar pekas ut av regeringen som särskilt viktiga i de direktiv som Skolverket fått om förändringar i skolans läroplan (Utbildningsdepartementet, 2015). Det finns just nu ett stort fokus på övergångar, vilket också i förlängningen kommer att påverka lärares arbete då förslag övergår till lagar, styrdokument och riktlinjer.

Vi har visat att Skolverkets (2014a) stödmaterial om övergångar främst kan ses som ett stöd för att skapa administrativa rutiner och kontroll i verksamheten och mellan verksamheterna. Fokus ligger på vilken kunskap/information som ska produceras (Foucault 1991) och överlämnas mellan institutioner, samt hur överlämnandet av information ska gå till. Materialet kan ses som ett bidrag till homogenisering av vilken typ av information som ska skapas och överlämnas. Det blir tydligt att det handlar om information om barnet i det administrativa systemet. Här ser vi också en styrning av informationsskapandet, vad som är möjligt att säga och göra vid övergångar i denna diskurs.

För lärares vardagsarbete kan sådana administrativa funktioner vara ett stöd, men materialet innehåller föga om de mer vardagliga aspekterna av lärares arbete med övergångar mellan verksamheter. Det är viktigt att skapa rutiner och administrativt stöd för övergångar, vilket medför att det är viktigt för förskolechefer, rektorer och andra ledningsfunktioner att ha kunskaper om materialet för att kunna effektivisera exempelvis resursfördelningen. Materialet säger däremot inte något om hur lärare ska 


\section{VENUE}

arbeta med övergångar i vardagen. Som lärare behöver man alltså ha en vidare kunskap om arbetet med övergångar än den som Skolverkets (2014) stödmaterial erbjuder. Simonsson och Lago (2015) visar till exempel att lärarna i förskoleklass är viktiga bärare av kunskap om förskoleklassen och dess arbete. Vi menar att det blir betydelsefullt att som lärare kunna förhålla sig till det men också att kunna förhålla sig kritisk när stödmaterial på en strukturell nivå ska omsättas i en pedagogisk praktik. Skolverkets material om övergångar blir viktigt att ha kännedom om och kunna förhålla sig till men det blir också viktigt att kunna förhålla detta till de specifika pedagogiska praktikerna (förskola, förskoleklass och grundskola) och deras uppdrag.

\section{Referenser}

Ackesjö, H. (2013). Från förväntningar till motstånd och anpassning: Fyra barns övergångar till och från förskoleklass. Nordic Early Education Research Journal. 6, 1-23. Corsaro, W. A. \& Molinari, L. (2005). I compagni: Understanding children's transition from preschool to elementary school. New York: Teachers College Press.

Davies, B. \& Harré, R. (1990). Positioning: The Discursive Production of Selves. Journal of Theory and Social Behaviour. 20(1), 43-63.

Ecclestone, K., Biesta, G. \& Hughes, M. (2010). Transitions in the lifecourse: The role of identity, agency and structure. I Ecclestone, K., Biesta, G. \& Hughes, M. (red.) Transitions and learning through the lifecourse. (s. 1-15). London: Routledge.

Foucault, M. (1991). Governmentality. I G. Burchell, C. Gordon, \& P. Miller (red.). The Foucault Effect: Studies in Governmentality. With two Lectures by and an Interview with Michael Foucault (s. 87-104). Chicago: University of Chicago Press.

Foucault, M. (2003). The subject and power. In P. Rabinow and N. Rose (red.). The essential Foucault: Selections from the essential works of Foucault 1954-1984 (s.126-144). New York: The new press.

Lago, L. (2014). "Mellanklass kan man kalla det": Om tid och meningsskapande vid övergången från förskoleklass till årskurs ett. Linköping: Linköping University. Margetts, K. (2002). Transition to school: Complexity and diversity. European Early Childhood Education Research Journal, 10(2), s. 103-114.

Rose, N. (1999). Powers of Freedom: Reframing political thought. Cambridge: Cambridge University Press. 


\section{VENUE}

Utbildningsdepartementet (2015). Regeringen stärker kvaliteten i fritidshem och förskoleklass. Pressmeddelande 2015-01-13.

Simonsson, M. \& Lago, L. (2015). Stöd eller styrning: En analys av Skolverkets stödmaterial för förskoleklassen. Venue.1(1) s. 1-6

Skolverket (2014a). Övergångar inom och mellan skolor och skolformer: Hur övergångar kan främja en kontinuitet i skolgången från förskolan till gymnasieskolan. Stockholm: Fritzes.

Skolverket (2014b). Förskoleklassen: Uppdrag, innehåll och kvalitet. Stockholm: Fritzes. Sutton, A., Muller, C. \& Langenkamp, A._G. (2013). High school transfer students and the transition to college: Timing and the structure of the school Year. Learning Sociology of Education, 86(1), s. 63-82.

' Med lärare avser vi den pedagogiska personalen i förskola, förskoleklass och skola. 